\title{
Organisational commitment: A key variable in the hotel sector of the province of Cordoba, Spain
}

\author{
Francisco González Santa Cruz ${ }^{1}$, Sandra Ma Sánchez Cañizares ${ }^{1 *}$ \\ and Tomás López-Guzman ${ }^{1}$
}

Received: 18/03/2013 Accepted: 12/07/2013

\footnotetext{
${ }^{1}$ Faculty of Labour Sciences, Department of Business Organisation, University of Cordoba. C/ Adarve, 30, 14071, Córdoba, Spain.

* Corresponding author; phone: +34 9572125 88; e-mail: sandra.sanchez@uco.es
}

\begin{abstract}
Businesses today face enormous challenges in differentiating themselves on the basis of tangible actions. As a result, human capital has become increasingly important over the last few decades as an element which provides added value to any business. More specifically in the hotel sector, employees play a fundamental role in client satisfaction and building customer loyalty since their organisational commitment is reflected in the improvement of quality standards in the services provided. Based on this idea, this paper aims to investigate the level of employee commitment in the hotel sector of the province of Cordoba (Spain) and its relationship to variables specific to the job position. Leading from this premise, it has been possible to arrive at the conclusion that the existence of part-time contracts reduces the level of employee commitment in contrast to permanent contracts, which clearly promote and develop commitment.
\end{abstract}

(C) 2014 International University College. All rights reserved

Keywords: Organisational commitment, human resources, hotel sector, Cordoba

Citation: González-Santacruz, F., S. Sánchez-Cañizares, T. López-Guzmán (2014) Organisational commitment: A key variable in the hotel sector of the province of Cordoba, Spain. European Journal of Tourism Research 7, pp. 109-126

\section{Introduction}

Within the current organisational environment, the business paradigm of adapting to change has a clear human aspect. The success of a company is only possible if it understands, analyses and implements measures which encourage employees to commit to their business projects and consider corporative objectives as personal ones, while business objectives should into account individual and group objectives which motivate employees. Moreover, business owners should pay attention to each area of employment and provide a personalised improvement programme which is directed at various groups in accordance with the employment characteristics of that group (Lee \& Way, 2010). 
There is empirical evidence which shows that customer satisfaction is, to a certain extent, a result of the satisfaction and commitment of employees (Larshon \& Shina, 1995; Schlesinger \& Heskett, 1991). The link between external clients and employees is found in the satisfaction and commitment of both parties as well as in the continuity of the relationship between them. In other words, the lower the level of employee turnover, the greater the continuity of the relationship and the greater the loyalty shown to the business is, by both, the employee and the client (Schlesinger \& Heskett, 1991). Perhaps the most pressing issue in the hotel sector is clients' perception of the quality of the service they have received as this is closely linked to the level of organisational commitment felt by employees (Hartline et al., 2003). The particular importance of this issue within the hotel sector is due to the fact that hotel management practices differ greatly from those of other kinds of businesses and organisations given the high level of contact between clients and employees.

Hotel establishments should therefore consider their employees as a source for obtaining sustainable long-term competitive advantages since their involvement and motivation are strategic elements which influence the quality of the service provided. Indeed, hotel employees who are more willing to share the values of the organisational culture, have a well-defined role within the organisation and are satisfied in their work are the ones who provide better customer service (Clark et al., 2009). Similarly, according to a study by Hawkings and Lee (1990) on the factors which lead hotel employees to demonstrate a certain degree of commitment to their organisation, commitment is strongly related to both job satisfaction and professional commitment. In any case, there are a series of determining factors or characteristics which can lead to the commitment (or not) or an individual (Galup et al., 2008). Furthermore, managers and directors of hotels must listen to the thoughts and concerns of their employees (Chiang, 2010).

Organisational commitment continues to be one of the most widely studied and challenging 110 subjects within the fields of management, organisational behaviour and human resources (Cohen, 2003). Organisational commitment is a key attitude, related to work, whose interest, from a business perspective, lies in its ability to influence the behaviour and decisions of employees within the framework of employment relations. The analysis of organisational commitment has gained increasing importance over the years, with the work of Porter et al. (1974) and Meyer and Allen (1984) having had the greatest impact in the field.

The start of the new decade has revealed itself to be the bearer of an unprecedented economic crisis. In spite of this difficult and dramatic situation, tourism is showing a high level of resistance to the worst consequence of the crisis, namely unemployment. Particularly noteworthy are the data from the latest World Tourism Organisation Barometer (2011), which show that tourism is directly responsible for $5 \%$ of the world's GDP ( $9 \%$ indirectly), represents $30 \%$ of world services trade and provides employment to one out of every twelve people across the globe. According to the International Labour Organisation (ILO, 2012), the world needs to create 600 million new jobs in the next decade in order to maintain economic growth. The ILO also states for every job created in tourism, one and a half is generated within the economy related to tourism.

Given the importance of the tourism sector, the aim of this paper is to use hypothesis testing in order to examine the influence of certain variables related to the job post (such as family dependence on income, type of contract with regards to working hours and stability, length of service, and gender) on employees' organisational commitment within the hotel sector of the province of Cordoba, Spain. To this end, this paper begins with the conceptualisation and dimensions of the construct and the formulation of hypotheses. This is followed by a description of the study area and the methodology employed to test the hypotheses. The most significant results of the analysis are then discussed. Finally, conclusions are reached, and the limitations of the study and future lines of research are presented. 


\section{Theoretical review}

The human capital lifecycle depends upon how long individuals remain within the organisation, which is in turn linked to job satisfaction at all levels. Organisational commitment is one of the mechanisms directors can use to analyse employees' loyalty and involvement with the organisation. Commitment exists amongst the members of an organisation when people identify with the company and when the objectives of the organisation and individual objectives are well-integrated and entirely congruent.

The Service-Profit Chain model (Reichheld, 1996) assumes that employee commitment can directly or indirectly improve the functioning and profitability of the organisation. The model proposes that motivated employees remain loyal and will work to the best of their ability. Indirectly, employee commitment improves the quality of customer service, which can lead to greater customer loyalty. In turn, customer loyalty stimulates profits and growth. It is an iterative system which continually feeds back on itself.

Commitment therefore involves a link which includes either behaviour or an attitude. It is necessary that this link brings with it a particular way of acting or a positive attitude towards an organisation which predisposes the individual to behave in such a way that will be of benefit to the organisation (Meyer \& Herscovitch, 2001). Commitment, however, goes beyond loyalty to include an active contribution towards achieving the organisation's goals. Moreover, it often reflects the agreement of the employee with the mission and goals of the organisation they work for, their willingness to exert effort to achieve them and their intention to continue working for the organisation (Davis \& Newstrom, 2001).

The organisational commitment construct has been a topic of research interest, principally due to the fact that it is associated with many of the main factors inherent to the success of a business, such as performance, absenteeism, employee turnover, and quality of working life as mentioned above (Porter et al., 1974; Mowday et al., 1982; Reichers, 1985; Griffin \&
Baterman, 1986; Mathieu \& Zajac, 1990; Meyer \& Allen, 1991; Salvador, 2005; among others). Many of the studies carried out on organisational commitment are multidisciplinary in nature, which has led to it being defined, measured and analysed in various ways over the years.

The origins of studies on commitment under the umbrella of organisational behaviour can be found primarily in the work of Porter and colleagues (Porter et al., 1974; Mowday et al., 1982 ). In the 1980s, after nearly a decade of research into the topic, Mowday et al. (1982) published a study which has become a clear point of reference for the academic community. In their research Mowday et al. (1982:27) defined organisational commitment as "the relative strength of an individual's identification with and involvement in a particular organisation".

In providing this definition, the authors indicated that they wanted to deal with three fundamental ideas (Mowday et al., 1982:176). Firstly, they concentrated on commitment to the organisation, with organisation being defined as a place of work. Secondly, they were interested in commitment towards the organisation as an attitude of employees. Thirdly, they took the point of view that the intrinsic nature of commitment had to mean something more profound and intense than a mere passive loyalty to the organisation. According to the authors, there are different ways of understanding commitment. It may be related to behaviours, that is to say an individual exertion centred around exceeding the established expectations, or related to attitudes, which represent the state in which the person identifies with the institution and its objectives and wishes to continue being a member of the organisation in order to facilitate the achievement of goals.

Moving forward in time to the 1990s, after reviewing the research on the organisational commitment construct, Mathieu and Zajac (1990) highlighted that a common theme running through the definitions of the construct referred to the links or ties an individual has with an organisation. Meyer and Allen (1991) 
referred to commitment in terms of a psychological state which characterises the relationship between a person and an organisation, where the expectations of both parties are very similar. Cotton (1993) stressed the participative nature of commitment, considering it to be a shared process resulting from combining information, influence and/or incentives where all individual abilities are used as a means of stimulating the attachment of employees to institutional success.

In the beginning of the $21^{\text {st }}$ century, Davis and Newstrom (2001) defined commitment as the extent to which an individual identifies with an organisation and wishes to continue participating actively in it. These authors maintained that commitment is usually stronger among employees with a longer tenure within an organisation (because they will have experienced personal success within the business) and among those who work within a group of committed employees. As defined by Arciniega (2002), organisational commitment is a set of linkages which keep a subject attached to an organisation. According to Testa (2001), organisational commitment can be an emotional response by the employee to a positive evaluation of the working environment. This response should be considered as an endorsement, particularly when the individual firmly believes in the values and goals of the organisation, or, when he or she shows a strong desire to stay within the organisation (Scholarios \& Marks, 2004).

Traditionally, models of organisational commitment have been developed using either a unidimensional or multidimensional approach. As regards the first approach, the model developed by Porter et al. (1974) is noteworthy. Although the authors refer to three dimensions in their definition of commitment as mentioned above, in their model they treat the construct as being unidimensional.

Reaching a consensus on how to model organisational commitment is a very difficult task, even more so when trying to arrive at a multidisciplinary theoretical framework. Nevertheless, the bulk of current research on organisational commitment accepts, and, is based on, the multidimensional model (Meyer et al., 2004). However, according to Meyer and Herscovitch (2001), there remains considerable disagreement about the multidimensional model due to:

$\checkmark$ Empirical evidence

$\checkmark$ Differences between earlier unidimensional concepts

$\checkmark$ Studies carried out within a theoretical context

$\checkmark$ A combination of these factors

As regards the multidimensional approach to organisational commitment, the model of Meyer and Allen (1984) was initially two-dimensional, but later extended to a three-component model.

In their initial model, the authors argued that the common ground between the existing definitions of organisational commitment was the fact that they can all be seen as a psychological state. They coincided with O'Reilly and Chatman (1986) in that the differentiating element between them is the nature of the psychological state. They, therefore, proposed a two-dimensional model for measuring commitment in which they distinguished between affective commitment and continuance commitment. Affective commitment can be characterised as intrinsic, in other words it is attributable to internal factors specific to the individual and their strong personal desire to remain with the organisation. Meyer and Allen (1984) characterised this dimension by the emotional union which employees feel towards the organisation. This is fixed by their identification with and involvement in the business as well as by their desire to remain within it in the future. Therefore, according to Meyer and Allen (1997), affective commitment is the most desirable form of commitment and that which organisations are most likely to want to instil in their employees. Through the affective component, employees who demonstrate this kind of commitment are inclined to work for the benefit of the organisation (Johnson \& Chang, 2006).

Moreover, they understood the second component (i.e. continuance commitment) to 
be the need an individual has to remain with an organisation without necessarily having any emotional links to it. An individual with a high level of continuance commitment perceives staying with the organisation as a necessity. This need is borne of individuals' binding choices (McGee \& Ford, 1987), which lead them to a situation where the costs associated with leaving the organisation are perceived as greater than the costs of staying. These binding costs may have different origins. For example, they may be linked to the sacrifices already made to remain with the organisation and those which arise from the lack of alternatives to the current organisation. To summarise, this dimension is related to the threat of loss as an factor inciting a person to commit to the organisation. This may be a result of the direct threat of loss (related to the value they attach to their current post) or by the indirect threat of loss (referring to the lack of alternatives to replace or improve upon the circumstances relative to their current job).

In the 1990s, Meyer and Allen (1990) extended their original two-dimensional approach (as discussed earlier) into a three-dimensional proposal by adding a third dimension which they called normative commitment. As Bergman (2006) highlighted, this third dimension was the most recent contribution and also the least studied. Its conceptualisation has varied since its beginnings (Allen, 2003). Initially, it was based on the internalisation of normative pressures to act in accordance with the organisation's interests. Over the years, it has come to focus on the feelings of obligation to stay with an organisation without addressing the social pressures of loyalty (Allen \& Meyer, 1996; Meyer et al., 1993). Recently - and in a subtle manner - this obligation has changed, alluding to benefits that invoke a need for reciprocity (Meyer et al., 2002).

The same authors, who defined this threedimensional approach, also argued that one of the most important reasons for distinguishing between the three conceptualisations is that each has different implications on behaviour. Meyer et al. (2002) corroborated this in the following way: affective commitment has a strong and positive correlation with desirable behaviours in the workplace; with normative commitment the relationship is weaker; and finally for continuance commitment there is no link with desirable behaviours. Thus the three dimensions of their model represent the three different ways in which an individual can be linked to an organisation. It could be said that individuals remain committed to the organisation because they want to (affective), because they need to (continuance) or because they feel obliged to (normative).

Moving onto another topic, it is important to point out that managers who develop and implement strategy within the hotel sector must evaluate and determine the factors (such as the working environment, working conditions, professional training and development, supervision, pay policies, working status etc.) that play an important role in providing what employees expect from employment (Lee \& Way, 2010). In having an understanding of these factors, organisations can design and develop suitable human resource policies to promote organisational commitment amongst employees. To contribute to achieving this objective, this study examines the importance of certain variables inherent to the job position in an attempting to demonstrate that these variables play a key role in commitment. To do so, the following hypotheses are put forward:

Hypothesis 1. Greater family dependence on salary leads to greater commitment.

The social sciences often employs the terms 'relative income' or 'reference income level' in order to make comparisons, while omitting the influence of absolute income on both constructs. Given these significant limitations to analysing the relationship between absolute salary and organisational commitment, we decided to formulate a hypothesis regarding the extent to which the family unit depends upon the hotel employee's salary as an indicator of relative income. In this line, some authors (Mathieu \& Zajac, 1990; Dunham et al., 1994; Mueller et al., 1994; Kim et al., 1996; Lam et al., 2001; among others) seem to agree that there is positive dependence (family income) with respect to relative income. However, the main difficulty lies in measuring it. 
For this reason, we have formulated a hypothesis on the level of dependence on the income earned and proposed the existence of a direct link between income and level of commitment.

Hypothesis 2. Permanent ${ }^{1}$ employees are more committed.

Given that organisational commitment focuses less on the temporal component and, above all, stability, this hypothesis holds that there is a direct link between job security derived from permanent or indefinite contracts and employees' organisational commitment, which lead to a greater emotional attachment to the organisation (Arnold \& Feldman, 1982; Greenhalgh \& Rosenblatt, 1984; Ashford et al., 1989; Van Dyne \& Eng, 1998; Buonocuore, 2010).

Hypothesis 3. The level of organisational commitment is lower for part-time ${ }^{2}$ employees.

The majority of studies analysed (Ross \& Wright, 1998; Van Dyne \& Eng, 1998; Sinclair et al., 1999) concluded that part-time employees show a lower level of organisational commitment. The above hypothesis has been put forward also taking into account the rationale, which arises from theories of partial inclusion and social exchange.

Hypothesis 4. Commitment increases with length of service.

Despite there being no clear line of investigation within scientific research, the most recent studies suggest a positive link between tenure and organisational commitment (Morris \& Sherman, 1981; Sarker et al., 2003; Kim \& Rowley, 2005; among others). This hypothesis has therefore been put forward considering length of service as a fundamental factor of socialisation within the company.

Hypothesis 5: There is no difference in the level of organisational commitment between genders.

Although there are very few studies on this topic and despite the fact that the work-life balance is more difficult to achieve in the hotel sector than in many other sectors, the above hypothesis has been put forward based on the most frequent jobs performed in the sector (Aranya et al., 1986; Jacobsen 2000).

\section{Description of the study area}

The study population for the field work consisted of staff from hotel establishments in the province of Cordoba, Spain. Due to its dynamic character and ability to create employment, the hotel sector in Cordoba plays a key role in the socioeconomic development of the province. This is especially important given the current economic crisis. According to the Working Population Survey 2011 conducted by the National Statistics Institute (NSI, 2012), unemployment in the province reached extremely worrying levels in the fourth quarter of 2011 , with $31.73 \%$ of the population unemployed (adults aged 16 and over). The hotel sector, however, is maintaining its levels of employment, as can be seen in Table 1.

As can be seen in Table 1, while the number of employed people in Cordoba across all sectors has fallen by 3686 between 2010 and 2011 (a figure which represents a decline of $1.38 \%$ in the total number of people in employment), the hotel sector has managed not only to maintain its level of employment, but actually improve it, with an average absolute increase of 39 people. This represents an increase of $3.07 \%$ within the sector, improving its relative significance by the end of the period studied to $0.54 \%$ of the total number of people employed.

These data only serve to confirm that this is a sector which should be supported since it has demonstrated an adequate level of employment growth during growth periods in the economic cycle and, at the same time, a significant level of resistance at times of economic recession, maintaining and even improving levels of employment. In order to attain these positive figures, Cordoba has differentiated its tourism offering by promoting quality cultural and rural tourism.

At the national level, Spain ranks among premier tourist destinations worldwide in terms of the number of arrivals and tourist 
Table 1. Working population in the province of Cordoba 2010-2011

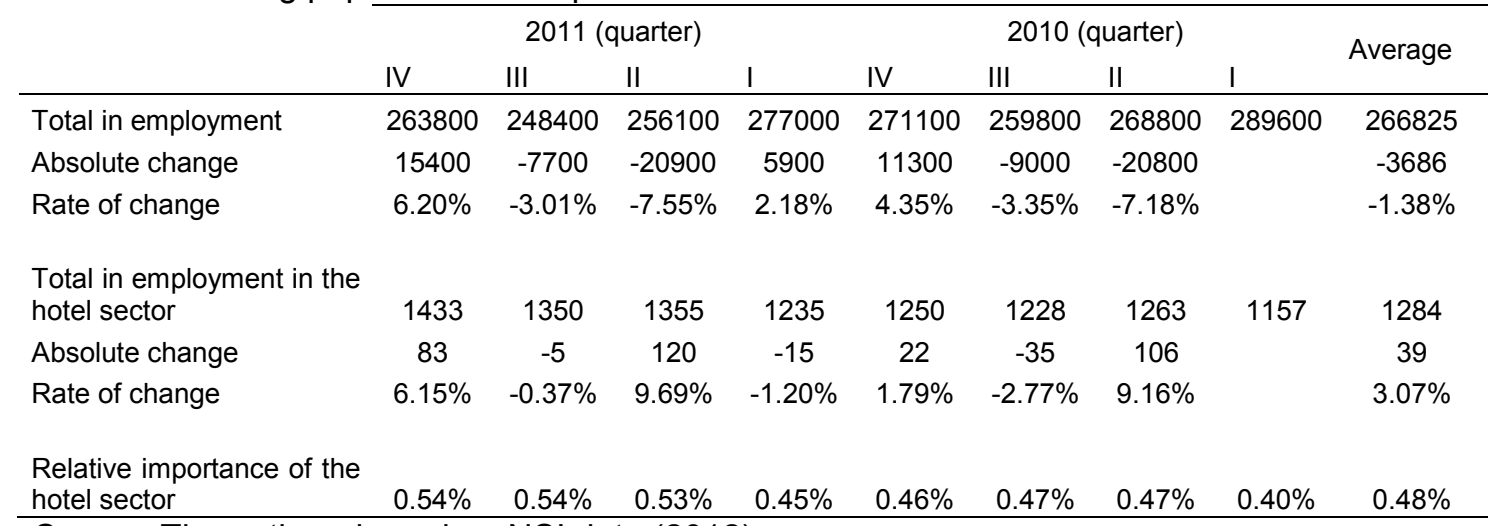

Source: The authors based on NSI data (2012)

Table 2. Key figures for the hotel sector in Cordoba

\begin{tabular}{lcccc}
\hline Stars & Number of hotels & Number of beds & Number of employees & Number of guests \\
\hline Five stars & 3 & 284 & 65 & 29597 \\
Four stars & 17 & 2271 & 506 & 388342 \\
Three stars & 23 & 1818 & 283 & 204516 \\
Two stars & 27 & 1365 & 135 & 89291 \\
One star & 17 & 877 & 85 & 57772 \\
\hline Total & $\mathbf{8 7}$ & $\mathbf{6 6 1 5}$ & $\mathbf{1 0 7 4}$ & $\mathbf{7 6 9 5 1 8}$ \\
\hline
\end{tabular}

Source: The authors based on HOSTECOR and NSI data

expenditure. In 2011, a total of 56.7 million international tourists came to Spain, representing a year-on-year increase of $7.6 \%$ or four million more tourists than in 2010 (NSI, 2010).

\section{Methodology}

As mentioned above, the importance of the hotel sector (excluding hostels and guesthouses) in the province of Cordoba prompted us to select this sector as the subject of the empirical study described in this paper. The vast majority of hotel establishments belong to the HOSTECOR business association. Specifically, $80 \%$ of all hotel establishments in the province and almost $100 \%$ of three-, four-, and five-star hotels are members of the association. These hotels employ the largest number of workers in the sector, providing $79 \%$ of total employment in the sector. Hostecor provided data on the location and category of the hotels which formed the basis for the field work of this study. The data provided by Hostecor was compared against data from the National Statistics Institute to develop Table 2.
The field work was carried out during the summer months of 2011. In the first phase of the field work, the hotels comprising the study were located (filtering out guesthouses and hostels, as already mentioned). In a second phase, the managers of the hotels were contacted personally by telephone to present the project and request their collaboration. In situ meetings were then arranged to explain the main objectives and distribute the corresponding questionnaires and blank envelopes.

A written questionnaire was considered to be a more appropriate methodology than personal interviews, telephone surveys or other interviewing methods, due to the advantages of this methodological approach, such as reduced costs, the high level of accessibility to the subject population and the lower probability of transcription errors when treating the data.

The questionnaire was composed of various sections, but for the purposes of this study we will focus on the section concerning the "General vision of organisational commitment" 
Table 3. Research specifications

\begin{tabular}{ll}
\hline Geographical scope & Provincial (Cordoba) \\
Target population: & Hotel staff \\
Population size: & 1,074 employees from 87 hotels. \\
Measurement instrument: & Structured and closed-ended questionnaire. \\
Sample size: & 585 \\
Response rate: & $54 \%$ \\
Error: & $2.735 \%$ \\
Data collection: & April-October 2011 \\
\hline
\end{tabular}

Table 4. Main quantitative results obtained

\begin{tabular}{lllllll}
\hline Stars & Hotels & Hotels surveyed & Response rate & Staff employed & Staff surveyed & Response rate \\
\hline Five & 3 & 3 & $100 \%$ & 65 & 53 & $82 \%$ \\
Four & 17 & 16 & $94 \%$ & 506 & 211 & $42 \%$ \\
Three & 23 & 20 & $87 \%$ & 283 & 167 & $59 \%$ \\
Two & 27 & 22 & $81 \%$ & 135 & 93 & $69 \%$ \\
One & 17 & 12 & $71 \%$ & 85 & 61 & $72 \%$ \\
\hline Total & $\mathbf{8 7}$ & $\mathbf{7 3}$ & $\mathbf{8 4} \%$ & $\mathbf{1 0 7 4}$ & $\mathbf{5 8 5}$ & $\mathbf{5 4 \%}$ \\
\hline
\end{tabular}

in line with the well-known Organisational Commitment Questionnaire (OCQ) developed by Porter et al. (1974). This is an easy-toadminister questionnaire which can be used by different organisations which have a large variety of employees. Furthermore, the decision to use a unidimensional scale (such as the OCQ of Porter et al.) was based on the drawbacks and criticisms of certain multidimensional scales. It should be noted that despite the fact that Allen and Meyer's (1990) three-dimensional approach to organisational commitment is the most widely accepted and has given rise to a vast amount of research, some issues must still be resolved, such as the overlap between the affective and normative dimension and the absence of a component of continuity as a form of commitment.

Nevertheless, the unidimensional scale of Porter et al. is widely used among organisational commitment researchers due to its sound psychometric properties. The OCQ consists of 15 items in which respondents are asked to indicate their level of agreement or disagreement on a five-point Likert scale. The scores obtained from the responses are added up and an average is calculated. The higher the result obtained, the greater the individual's organisational commitment. However, given that the questionnaire contains six items with negative statements $(3,7,9,11,12$ and 15$)$, it is necessary to invert the scale when calculating the average score.
Approximately two weeks after the initial contact, and following prior confirmation via telephone, each of the hotels was visited again in order to collect the sealed envelopes containing the completed questionnaires. Table 3 shows the research specifications.

Table 4 shows the initial results of the field work. As can be seen, 73 hotels of different categories completed the questionnaires, representing a response rate of $84 \%$. With regards to employee response rate, 585 questionnaires were completed in an adequate manner which represents $54 \%$ of the population. Therefore, it can be concluded that the results obtained, which will be the subject of description and analysis in the next section, are widely applicable to the general situation of the hotel sector in Cordoba.

The data were processed using the SPSS 15.0 programme for Windows and two groups of statistical techniques. A descriptive statistical analysis technique was used to obtain the basic data for the study, while ANOVA and multiple regression analysis were used to test the hypotheses on organisational commitment and identify potential links between several independent variables and the construct.

\section{Results and discussion}

As indicated above, the field work carried out for this research resulted in a final study sample of 585 correctly completed questionnaires, corresponding to 73 hotel 
Table 5. Composition of the sample (socio-professional variables)

\begin{tabular}{lcc|lcc}
\hline Variables & $\begin{array}{c}\text { Number of } \\
\text { respondent } \\
\text { s }\end{array}$ & Percentage & Variables & $\begin{array}{c}\text { Number of } \\
\text { respondents }\end{array}$ & Percentage \\
\hline Salary (€/month) & 17 & $2.9 \%$ & Permanent & 372 & $65.6 \%$ \\
$<=€ 500$ & 52 & $9.0 \%$ & Temporary & 195 & $34.4 \%$ \\
$€ 501-€ 750$ & 234 & $40.5 \%$ & & \\
$€ 751-€ 1,000$ & 245 & $42.3 \%$ & & \\
$€ 1,001-€ 1,500$ & 25 & $4.3 \%$ & & \\
$€ 1,501-€ 2,500$ & 6 & $1.0 \%$ & & \\
$>2,500$ & 433 & $80 \%$ & $\begin{array}{l}\text { Average length } \\
\text { of service at the } \\
\text { hotel (years) }\end{array}$ & \\
\hline Hours & 108 & $20 \%$ & & \\
Full-time & & &
\end{tabular}

Table 6. Gender/salary percentages

\begin{tabular}{lcccccccc}
\hline \multirow{2}{*}{ Monthly salary } & $<€ 500$ & $\begin{array}{c}€ 501- \\
€ 750\end{array}$ & $\begin{array}{c}€ 751- \\
€ 1000\end{array}$ & $\begin{array}{c}\text { Subtotal } \\
(-€ 1000)\end{array}$ & $\begin{array}{c}€ 1001- \\
€ 1500\end{array}$ & $\begin{array}{c}€ 1501- \\
€ 2500\end{array}$ & $>2500 €$ & $\begin{array}{c}\text { Subtotal } \\
(+\mathbf{1 0 0 0} €)\end{array}$ \\
\hline Male & $1.2 \%$ & $1.8 \%$ & $15.1 \%$ & $\mathbf{3 8 . 9 \%}$ & $24.2 \%$ & $3.3 \%$ & $0.9 \%$ & $\mathbf{6 1 . 1 \%}$ \\
Female & $1.4 \%$ & $7.2 \%$ & $25.6 \%$ & $\mathbf{6 3 . 9 \%}$ & $18.1 \%$ & $1.1 \%$ & $0.2 \%$ & $\mathbf{3 6 . 1 \%}$ \\
\hline
\end{tabular}

establishments in the province of Cordoba. Table 5 shows the results of the descriptive analysis of the socio-professional variables of the sample, which are applicable to the proposed hypotheses.

Based on the data shown in Table 5, some partial conclusions regarding the composition of the sample can be drawn:

1. There is a clear bipolarity when it comes to salary. The dividing line is $€ 1,000$ per month, with $47.6 \%$ of workers earning more this amount and $52.4 \%$ earning less. The large number of employees who earn less than $€ 1,000$ per month is due to the high proportion of women who work in the sector. As demonstrated in the literature, women earn lower salaries than men in the majority of tourism markets (Compos Soria et al., 2009). This is also evident in our sample since (as confirmed in Table 6 ) almost $64 \%$ of women earn less or equal than EUR 1000 compared to approximately $39 \%$ of men, while the figures are practically the inverse for monthly salaries above EUR 1000 euro.

2. Permanent or indefinite $(65.6 \%)$ and full-time ${ }^{3} \quad(80 \%)$ contracts are clearly considered to be a primary and stable source of employment. These types of jobs build a sense of identification with the organisation where the individual works (Buonocuore, 2010).

3. Similarly, the data appear to show stable a level of commitment to the hotel establishment since the average length of service at the hotels was 6.79 years.

The extent of organisational commitment was analysed according to the level of agreement, or disagreement, with the items in the questionnaire developed by Porter et al. (1974) as described earlier (Cronbach's alpha $=0.853$, thus indicating the reliability and validity of the scale used in the study). The results shown in Table 7 were measured on a scale of 1-5 after inverting items $3,7,9,11,12$ and 15 whose statements were negative as described above. Therefore, all the results closest to 5 indicate a higher level of involvement in and commitment to the organisation. Taking into account the overall mean score for all the statements, the mean commitment is 3.7238 with a standard deviation of 0.726 , which represents a relatively small dispersion. This indicates that the respondents have a mean commitment above the central value of 3 points.

According to the results presented in Table 7, one of the lowest scoring factors (3 points) in relation to organisational commitment is the lack of voluntary functional mobility in the hotel 
Table 7. Evaluation of items relating to organisational commitment

\begin{tabular}{|c|c|}
\hline Question & $\begin{array}{l}\text { Mean } \\
\text { response }\end{array}$ \\
\hline 1. I am willing to put in a great deal of effort in order to help this organisation be successful & 4.39 \\
\hline 2. I talk up this organization to my friends as a great organisation to work for. & 3.87 \\
\hline 3. I feel very little loyalty to this organisation. & 4.15 \\
\hline 4. I would accept almost any type of job assignment in order to keep working for this organisation. & 3.00 \\
\hline 5. I find that my values and the organisation's values are very similar. & 3.50 \\
\hline 6. I am proud to tell others that I am part of this organisation. & 4.03 \\
\hline 7. I could just as well be working for a different organisation as long as the type of work was similar. & 2.71 \\
\hline 8. This organisation really inspires the very best in me in the way of job performance. & 3.43 \\
\hline $\begin{array}{l}\text { 9. It would take very little change in my present circumstances to cause me to leave this } \\
\text { organisation. }\end{array}$ & 3.81 \\
\hline $\begin{array}{l}\text { 10. I am extremely glad that I chose this organisation to work for over others I was considering at } \\
\text { the time I joined. }\end{array}$ & 3.67 \\
\hline 11. There's not much to be gained by sticking with this organisation indefinitely. & 3.89 \\
\hline $\begin{array}{l}\text { 12. I often find it difficult to agree with this organisation's policies on important matters relating to its } \\
\text { employees. }\end{array}$ & 3.19 \\
\hline 13. I really care about the future of this organisation. & 4.25 \\
\hline 14. For me, this is the best of all possible organisations to work for. & 3.49 \\
\hline 15. Deciding to work for this organisation was a definite mistake on my part. & 4.37 \\
\hline Total mean organisational commitment & 3.7238 \\
\hline
\end{tabular}

sector ("I would accept almost any type job assignment in order to keep working for this organisation"). This highlights one the main problems within the Spanish economy in general and the service sector in particular, namely the lack of flexibility among the workforce to adapt to new stages of the economic cycle. Therefore, incentivising measures need to be put in place in order to support functional (and geographical) mobility. Especially when the general economic situation goes down the 'recession' route, such measures would permit businesses to adapt not only by reducing staff (as is happening now unfortunately), but also by developing an appropriate functional mobility policy (flexibility), which would allow employment to be maintained.
The need for such measures is even more pressing (if possible) within the hotel sector given that it encounters additional difficulties in planning human resources in a precise manner (quantitatively in terms of number of employees and qualitatively in terms of the necessary skills) due to the instability and seasonality of demand. There is no doubt that if the sector wishes to move towards the so-called 'flexicurity' (flexibility and job security), it will have to develop policies which make this very modern and important facet attractive to employees with a view to improving the productivity and competitiveness of organisations operating in the sector. European institutions are calling for this route to be followed in various productive sectors of the Spanish economy. 
Table 8. Mean differences and analysis of variance (ANOVA)

\begin{tabular}{|c|c|c|c|}
\hline Variable & Category & Commitment (mean) & $F$ (p-value) \\
\hline $\begin{array}{l}\text { Family dependence } \\
\text { on income }\end{array}$ & $\begin{array}{l}<40 \% \\
40 \%-75 \% \\
>75 \%\end{array}$ & $\begin{array}{l}3.61 \\
3.69 \\
3.78\end{array}$ & $\begin{array}{l}2.309 \\
(0.100)\end{array}$ \\
\hline Type of contract & $\begin{array}{l}\text { Permanent } \\
\text { Temporary }\end{array}$ & $\begin{array}{l}3.80 \\
3.60\end{array}$ & $\begin{array}{l}10.519 \\
(0.001)^{*}\end{array}$ \\
\hline Hours & $\begin{array}{l}\text { Full-time } \\
\text { Part-time }\end{array}$ & $\begin{array}{l}3.70 \\
3.75\end{array}$ & $\begin{array}{l}0.631 \\
(0.427)\end{array}$ \\
\hline $\begin{array}{l}\text { Length of service } \\
\text { (years) }\end{array}$ & $\begin{array}{l}<10 \\
10-20 \\
20-30 \\
>30\end{array}$ & $\begin{array}{l}3.70 \\
3.79 \\
3.61 \\
3.76\end{array}$ & $\begin{array}{l}0.435 \\
(0.728)\end{array}$ \\
\hline Gender & $\begin{array}{l}\text { Male } \\
\text { Female }\end{array}$ & $\begin{array}{l}3.74 \\
3.70\end{array}$ & $\begin{array}{l}0.378 \\
(0.539)\end{array}$ \\
\hline Number of stars & $\begin{array}{l}\text { One } \\
\text { Two } \\
\text { Three } \\
\text { Four } \\
\text { Five }\end{array}$ & $\begin{array}{l}4.02 \\
3.86 \\
3.56 \\
3.68\end{array}$ & $\begin{array}{l}6.219 \\
(0.000)^{*}\end{array}$ \\
\hline Department & $\begin{array}{l}\text { Administration } \\
\text { Accounts } \\
\text { Restaurant } \\
\text { Reception } \\
\text { Maintenance } \\
\text { Housekeeping } \\
\text { Kitchen } \\
\text { Management } \\
\text { Others }\end{array}$ & $\begin{array}{l}3.84 \\
3.71 \\
3.45 \\
3.73 \\
3.60 \\
3.78 \\
3.84 \\
3.73 \\
4.03 \\
3.67\end{array}$ & $\begin{array}{l}1.687 \\
(0.099)^{\star *}\end{array}$ \\
\hline
\end{tabular}

Table 9. Multiple regression analysis

\begin{tabular}{lllll}
\hline Variable & B coefficient & Error & $\boldsymbol{t}$ value & Significance \\
\hline Family dependence & 0.059 & 0.044 & 1.337 & 0.182 \\
Type of contract & 0.340 & 0.076 & 4.461 & $0.000^{*}$ \\
Time commitment & -0.233 & 0.089 & -2.607 & $0.009^{*}$ \\
Length of service (years) & 0.000 & 0.000 & -0.594 & 0.553 \\
Gender & -0.012 & 0.066 & -0.174 & 0.862 \\
Constant & 3.551 & 0.120 & 29.486 & 0.000 \\
R-squared & $42 \%$ & & & \\
\hline Note: ${ }^{*}$ Significant at 5\% & & & &
\end{tabular}

A bivariate analysis was performed to determine the influence of certain job-related variables on the level of commitment expressed by employees. This permitted us to test the veracity, or lack thereof, of the hypotheses proposed in section three on this construct. With this aim in mind, Table 8 shows the data from the analysis of variance (ANOVA) and the multiple regression analysis.

Some conclusions regarding employees' organisational commitment in the hotel sector in Cordoba and its relationship with certain variables can be drawn from the data in 
Table8. The idea is that these results can help hotel directors and managers to manage their human resources more efficiently, while gaining a better understanding of the principal factors that influence the commitment of the individuals they employ.

There is a notable statistical significance in the relationship between the following variables and organisational commitment:

1) The independent variables 'type of contract' and 'number of stars' show a statistical significance of $5 \%$, while 'department' has a significance level of $10 \%$ in relation to organisational commitment ${ }^{4}$.

2) Type of contract: As expected, there are significant differences in the means with respect to organisational commitment if the employee has a permanent or indefinite position (higher) rather than a temporary ${ }^{5}$ contract. Similarly, lack of job security increases the intention to leave the organisation since employees who view their continuance in the job as uncertain look for more secure jobs in the market (Arnold \& Feldman, 1982; Greenhalgh \& Rosenblatt, 1984; Ashford et al., 1989)

3) Number of stars: The relationship between hotel category (number of stars) and level of commitment follows a U-shaped curve, reaching its highest level for hotels with one star, only to fall steadily until it reaches its lowest point for hotels with three stars, and then begins its recovery and continues to grow steadily for four- and five-star hotels. One possible explanation for this is the nature of the relationship between the business or the owner (which in many cases relates to a selfemployed individual with few employees) and the employees of one-star hotels. This relationship is closer and almost family like, with employer and employee sharing both the best and worst moments of the business. However, it breaks down when a hotel expands and the number of stars increases, but fails to professionalise its human resources. In many cases it is in hotels with four or five stars (often part of large hotel chains) that the consideration, recognition, development and involvement of human capital is professionalised and managed through the corresponding human resources departments.

4) Department: There is a clear relationship between this variable and organisational commitment, with management (4.03) and housekeeping posts (3.84) showing higher mean levels of commitment. Although this may appear paradoxical, this conclusion makes sense. In the case of managers, their jobs entail greater responsibility, autonomy, initiative and knowledge (Mueller et al., 1994; Kim et al., 1996), while those working in housekeeping often have a lower level of education which in many cases leads them to demonstrate a high level of gratitude to the organisation for giving them the opportunity to be in paid employment, consequently increasing their level of organisational commitment to the business (Mathieu \& Zajac, 1990).

In what follows, we discuss the multiple regression analysis, whose aim was to determine a possible link between the independent variables (predictor and explanatory variables) and another dependent variable (criterion, explained or response variables), which in this case is mean organisational commitment. The independent variable was coded as follows:

$\checkmark$ Family dependence (a continuous variable which represents the percentage of the family income that is dependent upon the hotel employee's salary)

$\checkmark \quad$ Type of contract (0- temporary and 1permanent)

$\checkmark \quad$ Time commitment $(0-$ part time and 1 full time)

$\checkmark$ Length of service (a continuous variable which measures the number of years an individual has worked in the hotel sector)

$\checkmark$ Gender $(0$ - male and 1 - female)

Based on the results of the ANOVA test and multiple regression analysis, the hypotheses can now be accepted or rejected with respect to the dependent variable 'organisational commitment'. 
Hypothesis 1. Greater family dependence on salary leads to greater commitment.

The ANOVA test showed that the relationship between family dependence on income earned (as a concept similar to relative income) and organisational commitment is increasing, with the mean difference significant at the $10 \%$ level. However, the multiple regression analysis shows a positive coefficient, but is not statistically significant. Therefore, Hypothesis 1 must be rejected, in line with the study of Lam et al. (2001).

A traditional explanation for this result can be found in Maier (1963). Maier's study showed that the influence of non-economic factors on employees' satisfaction and commitment - and the relative importance of salary on satisfaction and commitment - was already recognised as early as the 1930s. Moreover, according to Clark (1996), it is possible that this result is due to the existence of unobservable variables which are jointly associated with income and level of job satisfaction and commitment. Furthermore, if one of the functions of the salary is to compensate employees for performing difficult jobs, the best paid individuals would have to be carrying out the most difficult jobs. Therefore, these employees will not necessary be the most committed to the organisation which employs them.

Groot and Maasen van den Brink (1999) provided another possible explanation. They argued that even though introducing wage rises increases job satisfaction and organisational commitment in principle, once workers get used to the new wage level, the effect of the increase in salary is no longer effective. Moreover, Gaertner (1999) introduced the concept of 'distributive justice', which has been shown to be a determinant of the extent of commitment to the organisation. According to this author, it is not the monetary value of the employees' income which affects their level of commitment, but rather the perception of justice and equity in relation to the salary.

\section{Hypothesis 2. Permanent or indefinite employees are more committed. \\ In principle, it appears logical that when linking the type of contract (in terms of duration) to organisational commitment the analysis of}

variance determines that the statistical significance in the mean differences of commitment for this variable. This highlights the higher level of commitment in permanent employment relations, such as those derived from a permanent or indefinite contract. This result is maintained and confirmed with the multiple regression analysis in which the positive and significant coefficient (coded as 0 = temporary contract, 1 = permanent contract) determines the rejection of the independence of variables analysed and the greater level of commitment to the business where the individual is employed when the employment contract is unlimited in its timespan, thus confirming the conclusions of Greenhalgh and Rosenblatt (1984) and Nikolaou et al. (2005). Therefore, the hypothesis as presented is admitted.

\section{Hypothesis 3. Organisational commitment is lower for part-time employees.}

The results obtained from the analysis of variance determine the absence of statistical significance in the mean difference for commitment shown in the two categories of the variable 'time commitment' (part-time and fulltime). Nevertheless, multiple regression analysis shows a negative (in favour of those contracted on a part-time basis) and significant coefficient, which determines the rejection of independence between both variables. In this sense, the hypothesis is not accepted in the terms it has been presented and therefore it cannot be stated that a greater time commitment to employment in the hotel determines an improvement in the level of organisational commitment towards the business, but in fact the contrary. These results coincide with those of Still (1983) and, more recently, Thorsteinson (2003).

Perhaps the most evident explanation for this result is related to the 'Theory of Partial Inclusion'. On the basis of this theory, individuals are members of multiple social systems in which they play different roles in different areas of their life (Katz \& Kahn, 1978). From this perspective, the extent and flexibility of working hours, characteristic of the hotel sector, make it difficult to establish the necessary balance between work and home life 
(Eberhardt \& Shani, 1984; Edwards \& Robinson, 2001). This is even more significant in employment sectors with a high female presence. Therefore, organisational commitment can increase when part-time stable employment allows the employee to become more involved in other social, recreational and, above all, family activities.

\section{Hypothesis 4. Commitment increases with length of service.}

From the review of the average commitment demonstrated by employees in relation to their length of service, no clear tendency line has been found. Although commitment increases marginally from joining the company up to 20 years of tenure, from this point onwards a fall is recorded which does not recover until employees have spent 30 years with the company. This initial conclusion is also confirmed by the lack of statistical significance in the analysis of variance in which there exists no clear mean difference in organisational commitment for this variable. The multiple regression analysis shows a neutral and nonsignificant coefficient which leads to the conclusion that a shorter or longer length of service does not lead to a reduction or increase in the level of commitment. Therefore, the hypothesis that commitment increases with tenure must be rejected in line with the conclusions of Ríos Manríquez et al. (2010).

One argument which can explain this reduction in organisational commitment with increasing length of service is the loss of interest in the work itself. In many job posts this could be due to the lack of variety and the lack of professional career development plans and updating of knowledge. This leads to a low desire to assume responsibility and remain involved as the length of time in the position increases. For their part, Smith et al. (1996) detected a higher level of commitment amongst those employees with a shorter length of service within the organisation, resulting from the enthusiasm which comes along with beginning a new job. After this initial period, the level of commitment falls substantially.

Hypothesis 5: There is no difference in the level of organisational commitment between genders.
There is no significant difference in the average value for commitment between genders, which is confirmed by the lack of statistical significance in variance analysis and in the multiple regression analysis which provided a negative coefficient $(-0.012)$. With the variable recoded as $1=$ male and $2=$ female, this would determine a higher level of commitment for female employees, although not significantly. Therefore, the results allow the hypothesis as presented to be accepted and confirm that there is no link between the gender of the individual and their level of organisational commitment.

\section{Conclusion}

In the current economic environment of globalisation, rapid change and competitiveness, human resource management has become much more complex and its efficacy depends to a large extent on the achievement of an organisation's objectives. With regards to human capital, organisational commitment emerges as an adequate means of measuring its importance. High levels of commitment will make it possible to maintain general collective skills and sustainable longlasting competitive advantages achieved by the organisation.

All of these issues are, if possible, even more important in the tourism sector and the hotel sector in particular due to the intense contact which occurs between the client and the employee. Thus, employee commitment will support the generation of customer loyalty as a result of the high quality provision of service extended to them

It is on the basis of this idea that this paper has attempted to extract a series of practical conclusions which will provide managers of bodies in the hotel sector with the knowledge about how diverse variables inherent to the job post can influence organisational commitment and, by extension, the success of the business. With this, the aim is also to provide the knowledge which will allow organisational improvement measures to be carried out. Instead of the classic approach of adapting individuals to suit their job description, these measures have the opposite aim, that is, the 
professional enrichment of the employee should take precedence in order to increase job satisfaction in the first instance and ultimately organisational commitment.

The results obtained have demonstrated the existence of a marked salary bipolarity with a clear dividing line, emerging between those who earn more than 1000 euro monthly and those who earn less. It has also been possible to see the sector does not function on the basis of precarious or unstable employment but rather the majority of employment relations are regulated by full-time, permanent contracts. These jobs are therefore considered to be the main source of employment with a significant level of stability given the average length of service within the sector, which at the same time, presents an intermediate level of commitment.

In the hypothesis testing, with respect to the links between the stated variables related to the job and employees' organisational commitment, it is important to point out that family dependence upon the income obtained from working in the sector and the length of service have no clear links with the expressed level of commitment. However, when the variables working day and the level of stability with regards to the type of contract were analysed it was clear to see that part-time work does not imply an improvement in organisational commitment. Furthermore, the existence of a permanent contract supports employees' organisational commitment. This appears logical when the philosophy of double commitment is considered, something which occurs when there is mutual trust between both parties and which primarily develops within a working context through stable contracts.

The main limitation of these kinds of study is the subjectivity of the constructs, such the one analysed and disparities in interpretation which make it difficult to develop universal measures which would allow for a more uniform and profound study. The academic community should join forces and support research in the same direction, with irrefutable parameters and uniform instruments of evaluation, with the aim of reaching conclusions which can be applied in a generalised way. This is necessary in order to understand the process by which employees become committed to the organisation which employs them.

Future lines of research recommended include the study of the link between variables in the management of hotels, such as outsourcing of tasks and the application of employee benefit participation systems and how these would affect organisational commitment. Furthermore, the size of the hotel establishment should be the subject of a separate analysis, due to the existence of very specific and varied management practices among large and small hotels, whereby large hotels operate a professional management system and small hotels have a family-like atmosphere.

\section{Endnotes:}

${ }^{1}$ A permanent or indefinite contract is one which has no expiry date. In other words, it is agreed that the employee will provide their services for an unlimited period of time.

2 A part-time contract is one in which an employee is obliged to provide services for a determined number of hours either per day, per week, per month or per annum. The number of working hours is less than the number of hours normally established to perform the job.

${ }^{3}$ Full-time contracts are contracts in which employees work the maximum number of hours per week as established by law. In Spain, this is normally 40 hours per week.

${ }^{4}$ Specific hypotheses have not been formulated for the variables 'number of stars' and 'department' due to the lack of literature on the subject which could serve as a foundation for the hypotheses.

${ }^{5} \mathrm{~A}$ temporary contract is defined as a contract for a limited duration of time.

\section{References}

Allen, N. J. (2003). Examining organizational commitment in China. Journal of Vocational Behavior, 62, 511-515.

Allen, N. J. \& Meyer, J. P. (1990). The measurement and antecedents of affective, continuance and normative commitment to the organization. Journal of Occupational Psychology, 63, 301-320.

Allen, N. J. \& Meyer, J. P. (1996). Affective, continuance and normative commitment to the organization: an examination of construct validity. Journal of Vocational Behavior, 49, 252-276.

Aranya, N.; Kushnir, T. \& Valency, A. (1986). Organizational commitment in a male- 
dominated profession. Human Relations, 39, 433-448.

Arciniega, L. (2002). Compromiso organizacional México Cómo hacer que la gente se ponga la camiseta? México: Limusa.

Arnold, H.J. \& Feldman, D. C. (1982). A multivariate analysis of the determinants of job turnover. Journal of Applied Psychology, 67, 350-360.

Ashford, S. J., Lee, C. \& Bobko, P. (1989). Content, causes and consequences of job insecurity: a theory-based measure and substantive test. Academy of Management Journal, 32(4), 803-820.

Bergman, M. E. (2006). The relationship between affective and normative commitment: review and research agenda. Journal of Organizational Behaviour, 27, 645-663.

Buonocuore, F. (2010). Contingent work in the hospitality industry: A mediating model of organizational attitudes. Tourism Management, 31, 378-385.

Campos Soria, J. A., Ortega-Aguaza, B. \& Ropero García, M. A. (2009). Gender segregation and wage difference in the hospitality industry. Tourism Economics, 15(4), 847-866.

Chiang, C. (2010). Perceived organizational change in the hotel industry: An implication of change scheme. International Journal of Hospitality Management, 29, 157-167.

Clark, A. E. (1996). Job satisfaction in Britain. British Journal of Industrial Relations, 34, 189-217.

Clark, R. A., Hartline, M. D. \& Jones, K. C. (2009). The effects of leadership style on hotel employees' commitment to service quality. Cornell Hospitality Quarterly, 50, 209-231.

Cohen, A. (2003). Multiple commitments at work: An integrative approach. Hillsdale: Lawrence Erlbaum.

Cotton, J. L. (1993). Employee involvement. New York: Sage.

Davis, K. \& Newstrom J. (2001). Human behavior at work. 11 th edition, Mexico: McGraw Hill.

Dunham, R. B., Grube, J. A. \& Castaneda, M. B. (1994). Organizational commitment: the utility of an integrative definition. Journal of Applied Psychology, 79, 370-380.

Eberhardt, B. J. \& Shani, A. B. (1984). The effects of part-time versus full-time employment status on attitudes toward specific organizational characteristics and overall job satisfaction. Academy of Management Journal, 27(4), 893900.

Edwards, C. \& Robinson, O. (2001). Better part-time jobs? A study of part-time working in nursing and the police. Employee Relations, 23(5), 438-453.

Gaertner, S. (1999). Structural determinants of job satisfaction and organizational commitment in turnover models. Human Resource Management Review, 9(4), 479-493.

Galup, S., Klein, G. \& Jiang, J. (2008). The impacts of job characteristics on IS employee satisfaction: a comparison between permanent and temporary employees. Journal of Computer Information Systems, 48(4), 58-68.

Greenhalgh, L. \& Rosenblatt, Z. (1984). Job insecurity: toward conceptual clarity. Academy of Management Review, 9, 438-448.

Griffin, R. W. \& Bateman, T. S. (1986). Job satisfaction and organizational commitment. In Cooper, C. L. \& Robertson, I. (Eds.). International Review of Industrial and Organizational Psychology, (pp. 99-102), Chischester: Wiley \& Sons.

Groot, W. \& Maasen Van Den Brink, H. (1999). Job satisfaction of older workers. International Journal of Manpower, 20, 343-360.

Hartline, M. D., Wooldridge, B. R. \& Jones, K. C. (2003). Guest perception of hotel quality: determining which employee groups count most. Cornell Hotel and Restaurant Administration Quarterly, 44(1), 43-52.

Hawkings, D. E. \& Lee, Y. T. (1990). An empirical analysis of organizational commitment among American hotel sales and marketing professionals". Hospitality Research Journal, 14(2), 103-112. 
International Labour Organization (2012). Global Employment Trends 2012: Preventing a deeper jobs crisis. Geneva (Switzerland).

Jacobsen, D. I. (2000). Managing increased part-time: does part-time work imply part-time commitment? Managing Service Quality, 10, 187-200.

Johnson, R. E. \& Chang, C. H. (2006). -I- is to continuance as - we - is to affective: the relevance of the self-concept for organizational commitment. Journal of Organizational Behaviour, 27(5), 549570.

Katz, D. \& Kahn, R. L. (1978). The social psychology of organizations. New York: Wiley.

Kim, J. W. \& Rowley, C. (2005). Employment commitment: a review of the background, determinants and theoretical perspectives. Asia Pacific Business Review, 11, 105-124.

Kim, S. W., Price, J. L., Mueller, C. W. \& Watson, T. W. (1996). The determinants of career intent among physicians at a U.S. Air Force hospital. Human Relations, 49, 947-975.

Lam, T., Zhang, H. \& Baum, T. (2001). An investigation of employees' job satisfaction: the case of hotels in Hong Kong. Tourism Management, 22, 157 165.

Larson, P. D. \& Sinha, A. (1995). The TQM impact: A study of quality managers' perceptions. Quality Management Journal, 2(3), 53-66.

Lee, C. \& Way, K. (2010). Individual employment characteristics of hotel employees that play a role in employee satisfaction and work retention. International Journal of Hospitality Management, 29, 344-353.

Maier, N. R. F. (1963). Industrial psychology. Madrid: Rialp.

Mathieu, J. E. \& Zajac, D. M. (1990). A review and meta-analysis of the antecedents, correlates, and consequences of organizational commitment. Psychological Bulletin, 108, 171-194.

McGee, G. W. \& Ford, R. C. (1987). Two (or more) dimensions of organizational commitment: re-examination of the affective and continuance commitment scales. Journal of Applied Psychology, $72,638-642$.

Meyer, J. P. \& Allen, N. J. (1984). Testing the 'side-bet theory' of organizational commitment: Some methodological considerations. Journal of Applied Psychology, 69, 372-378.

Meyer, J. P. \& Allen, N. J. (1991). A three component conceptualization or organizational commitment. Human Resource Management Review, 1, 6189.

Meyer, J. P. \& Allen N. J. (1997). Commitment in the workplace: Theory, research and application. Thousand Oaks: Sage Publications.

Meyer, J. P., Allen N. J. \& Smith C. A. (1993). Commitment to organizations and occupations: extension and test of a three-component conceptualization. Journal of Applied Psychology, 78, 538-551.

Meyer, J. P., Beckert. E. \& Vandenberghec (2004). Employee commitment and motivation: a conceptual analysis and integrative model. Journal of Applied Psychology, 89(6), 991-1007.

Meyer, J.P. \& Herscovitch, L. (2001). Commitment in the workplace. Toward a general model. Human Resource Management Review, 11, 299-326.

Meyer, J. P., Stanley, D. J., Herscovitch, L. \& Topolnytsky, L. (2002). Affective, continuance, and normative commitment to the organization: A meta-analysis of antecedents, correlates and consequences. Journal of Vocational Behavior, 61, 20-52.

Morris, J. \& Sherman, J. D. (1981). Generalizability of an organization commitment model. Academy of Management Journal, 24, 512-526.

Mowday, R. T., Porter, L. W. \& Steers, R. M. (1982).

Employee-organization linkages: The psychology of commitment, absenteeism and turnover. New York: Academic Press.

Mueller, C. W., Boyer, E. M., Price, J. L. \& Iverson, R. D. (1994). Employee attachment and non-coercive conditions of work: The case of dental 
hygienists. Work and Occupations, 21, 179-212.

National Statistics Institute (2012). Economically active population survey. Madrid: Publications Services.

Nikolaou, A., Theodossiou, I. \& Vasileiou E. G. (2005). Does job security increase job satisfaction? A study of the European experience. Presentation at the 2nd World Conference SOLE/EALE, European Association of Labour Economists, San Francisco.

O'Reilly, C. A. \& Chatman, J. (1986). Organizational commitment and psychological attachment: The effects of compliance, identification and internalization on prosocial behaviour. Journal of Applied Psychology, 71, 492-499.

Porter, L. W., Steers, R. M., Mowday, R. T. \& Boulian, P. V. (1974). Organizational commitment, job satisfaction and turnover among psychiatric technicians. Journal of Applied Psychology, 59, 603-609.

Reichers, A. E. (1985). A review and reconceptualization of organizational commitment. Academy of Management Review, 10, 493-512.

Reichheld F. F. (1996). The loyalty effect. Boston: Harvard Business School Press.

Ríos Manríquez, M., Télle Ramírez, M. R. \& Ferrer Guerra, J. (2010). El empowerment como predictor del compromiso organizacional en las pymes. Redalyc: Contaduría y Administración, 231, 103-125

Ross, C. E. \& Wright, M. P. (1998). Women's work, men's work, and the sense of control. Work and Occupations, 25, 333-355.

Salvador, C. (2005). Components of commitment and its influence on customer satisfaction. Journal of Psychology, 20 (3), 316-322.
Sánchez Cañizares, S. M. (2006). Diseño de un modelo causal de satisfacción laboral: aplicación en el sector servicios. Tesis Doctoral. Universidad de Córdoba, Córdoba.

Sarker, S. J., Crossman, A. \& Chinmeteepituck, P. (2003). The relationships of age and length of service with job satisfaction: an examination of hotel employees in Thailand. Journal of Managerial Psychology, 18(7-8), 745-758.

Schlesinger, L. A. \& Heskett, J. L. (1991). Breaking the cycle of failure in services. MIT Sloan Management Review, 32(3), 17-28.

Scholarios, D. \& Marks, A. (2004). Work-life balance and the software worker. Human Resource Management Journal, 14(2), 54-74.

Sinclair, R. R., Martin, J. E. \& Michel, R. P. (1999). Full-time and part-time subgroup differences in job attitudes and demographic characteristics. Journal of Vocational Behavior, 55, 337-357.

Still, L. V. (1983). Part-time versus full-time salespeople: individual attributes, organizational commitment, and work attitudes. Journal of Retailing, 59, 5579.

Testa, M. R. (2001). Organizational commitment, job satisfaction, and effort in the service environment. The Journal of Psychology, 135(2), 226-236.

Thorsteinson, T. J. (2003). Job attitudes of part-time vs. full-time workers: a metaanalytic review. Journal of Occupational and Organizational Psychology, 76, 151-177.

Van Dyne, L. \& Eng, S. (1998). Organizational citizenship behaviour of contingent workers in Singapore. Academy of Management Journal, 41, 692-703.

World Tourism Organization (2011). Tourist data. Publication Services. Madrid. 